\title{
THE IMPLEMENTATION OF HANGING BALL EXERCISE FOR IMPROVING KEDENG SMASH ABILITIES IN TAKRAW LEARNING
}

\author{
Yarmani \\ Universitas Bengkulu, email : yarmani@unib.ac.id \\ Syafrial \\ Universitas Bengkulu, email : syafrial@unib.ac.id \\ Arwin \\ Universitas Bengkulu, email : arwin@unib.ac.id
}

\begin{abstract}
This study aims to apply the hanging ball exercise to improving kedeng smash ability in sepak takraw learning. This research method uses applied research, one of the studies uses a classroom action research approach. The sample used in this study is 33 students of Physical Education's soccer takraw course. The research procedure is cycle form. Each cycle consists of four stages including: planning, implementing actions, observing and reflecting. Data collection technique through observation and test. This data collection uses observation sheets instruments of student and lecturers' performance in the learning process, to determine the quality of student learning outcomes used an evaluation or test sheet. The results showed that the application of hanging ball exercises in improving the ability to kedeng smash in sepak takraw learning can improve student learning outcomes in sepaktakraw courses from an average pre-cycle value of 10 points (50\%), to 15 points (80\%) in cycle 1 and the average value of 12 points prasiklus (60\%), to 16 points (85\%) in cycle 2.
\end{abstract}

Keywords: hanging ball exercises, kedeng smash, sepak takraw

\section{INTRODUCTION}

Sepak Takraw Learning Course is one of the elective courses in the Physical Education study program where students who choose this course will go through the learning process about sepak takraw for one semester. Students required to be able understand technique of kedeng smash in sepak takraw. One of the basic material that must be mastered with minimum standard of sepak takraw is sepak takraw material, specifically at the movement from kedeng Smash based on the results of lectures in 2017-2018 not achieving the expected target, students get excellent grades about $10 \%$, good grade about $17 \%$, a sufficient value about $33 \%$, and a value less than $40 \%$., These results certainly do not meet both the passing grade standards, as well as individual minimum standards.
Some constrained things of Sepak takraw in Physical Education students, based on the preliminary research results, revealed that; 1 ) most of the students have not understand kedeng smash in correct, 2) students are not fast enough in doing kedeng smash, 3 ) kedeng smash students are still not right due to the above problems, interest, and motivation to Sepak takraw learning is still low, students tend just follow what lectures course but not really serious in studying kedeng smash technique. This might be due because there're nothing learning media, so the lecturer needs to apply the media of learning the practice of hanging ball in the soccer takraw in improving learning outcomes. Meanwhile the problem also because 1) equipment and tools to practice do not support the students needs to do 
exercises with sufficient frequency, it is because of the limited equipment available with a sufficient number of students of 35 people/ class; 2) The Takraw Room on the campus is actually too small for the students, so the area of student practice is very limited; 3 ). The absence of learning media so that students feel bored and monotonous.

Some of the situations and conditions as obstacles or obstacles to the sepak takraw learning process that have been stated above, it is necessary to have steps in order to explore the learning process to be more effective and efficient and the learning outcomes also increase. In other cases after students complete their studies, students are expected to be able to present learning to their students well with the right strategy, able to teach students actively, innovative, creative, efficient and fun (Paikem). One of the steps in order for good learning to occur, teachers should shift their views from teaching as a source of authority to their role as creative facilitators and mediators, so as to develop students' thinking abilities (Widi, 2007: 2).

According to Mosston \& Asworth, 1994 in Irwandi (2009: 55) said that teachers must take a new approach, by applying and utilizing a variety of teaching abilities, teaching methods and styles that can effectively with specific learning environments, unique and typical, this learning can improve the students ability in learning process. In Indonesian dictionaries, learning is trying to having intelligence or knowledge. Here are various learning understandings according to experts. According to Gage, learning is a process which an organization changes its behavior. According to Skinner, learning is a adaptation process or behavior adjustment that takes place progressively. Learning also understood as a behavior, when people learn, the response becomes better, if do not, the response decreases.Thus, learning interpreted as a possibilities change or the response chance.

Noehi Nasution said that, learning is a process that allows the emergence or change of a behavior as formation result of the main response, with the condition that the change or the emergence of new behavior is not caused by maturity or temporary changes due to a thing. Snelbecker talked that, learning is to include behavior from the simplest to the most complex where the change process must be self controlled by external factors.

The learning process occurs internally and is personal in students, so that the learning process leads to objectives achievement in the curriculum, the instructor or teacher must plan carefully and systematically various learning experiences that enable changes in student behavior accordance with what expected. When the learning process occurs, together with that the teaching process occurs. This would be easy to understand because if there is learning, of course there will be those who teach and vice versa. In the teaching and learning process, teachers as instructors and students of learning subjects, are required to have a certain qualification profile in terms of knowledge, abilities, attitudes and values, as well as personal traits, so that the process can take place effectively and efficiently.

\section{METHODS}

This research method uses applied research (Applied Research), one of these studies uses the Classroom Action Research approach. Classroom Action Research (CAR) is one alternative applied research to improve and improve learning performance in the classroom or field (Carr \& Kemmis 1991, in IGK Wardani, 2007). 


\section{RESULTS AND DISCUSSION}

Characteristics of Subjects and Research Objects.This study's subjects were 1) the lecturer supporting the Takraw course, which in this case was act as a researcher, and 2) who were given treatment were 7 semester students in 2019 academic year totaling 33 people (27 men and 6 women). The Sepak Takraw course is an elective course in odd semester where the sub-section is kedeng smash so this material must be mastered by Physical Education students.

Students who take this course, all are adults, meaning that physically can support to follow this material properly. Based on experience, the Sepak Takraw course is an elective subject that is less desirable because of the difficulty level in doing the Smash Technique. Good kedeng smash because it takes good technique and continuous repetition in order to do it perfectly. To support learning, the conditions of learning equipment and lecture facilities are quite adequate. In addition to the field that is used, namely Takraw hanging ball, net, and ball.

Process and Findings in Pre-Cycle

At the beginning of the activity, the researcher conducted an initial test. This preliminary test or pre-test held to determine the extent of student's abilities in conducting kedeng Smash before applying the application of hanging ball media. From this preliminary data acquisition, it can be seen that most of the students have difficulty doing the kedeng Smash movement, the findings are: learning outcomes of kedeng Smash in male students are better than female students. 27 male students only 6 people or only $10 \%$ who succeed in mastering and skilled in the kedeng Smash, while the other $90 \%$ of students have not mastered and not yet skilled, but overall in the class, as follows:

1) $90 \%$ of students cannot kedeng smash perfectly.
2) The movement technique of body dan it's position still rigid, meaning that it is less agile.

3) Kedeng smash kicks are less accurate and inaccurate.

4) There is no media to facilitate students in doing Smash.

From these initial findings, it was concluded that the difficulties of students in conducting the kedeng Smash were caused by the 4 factors above.Implementation of learning improvement actions.

Planning

a. Findings in the pre-cycle used as the basis for researchers to plan research steps. The first step taken by researchers together with fellow lecturers before the action was carried out included identifying data on the results of student skills tests obtained from the initial skills tests as well as observations of the kedeng smash series of assessment factors, namely active or passive students and students who have less and less ability. Formulate problems in learning, then formulate the work patterns of students in learning with the application of hanging ball media in Sepak Takraw. Prepare learning plans, and student observation sheets.

b. As a research planning product, researchers or lecturers have prepared a Semester Learning Plan (RPS) by implementing the hanging ball media. Learning in cycle 1 is presented in 2 meetings (sub-actions).

Implementation of Action

The first cycle of learning activities, the first meeting held on Monday, June 26, 2019 , and the second meeting on July 3 , 2019 each presented for 2 lesson hours (2x50 minutes). The application of hanging ball media is presented in the form of training groups, each group consisting of 6 people. Learning Steps using the kedeng smash Instructional Hanging Ball Media:

a) Classically/together students observe the kedeng smash 
instructional video through a hanging ball that is aired via Infokus.

b) Students observe carefully, and note the important things of each movement from the beginning to the end together.

c) Each group gradually practices the Kick Technique repeatedly and focuses on doing the kedeng smash during learning.

Observation Results of Cycle 1

a. During the learning process of the first cycle which was presented in 2 meetings the researchers noted several things, including students being very motivated to do the kedeng smash kick exercise using a hanging ball.

b. Observation using the lecturer and student observation sheets during learning taken 6 students randomly. Students who are sampled are a representation of all students who represent and show the conditions of learning in the class. Observation of the activities of students and lecturers recorded for 90 minutes at the first meeting with the data in the following table:

Table 1. Results of observations of the effective time of the first cycle of

\begin{tabular}{l|l|r|c}
\multicolumn{5}{c}{ learning } \\
No & $\begin{array}{l}\text { Student And } \\
\text { Lecturer } \\
\text { Activities }\end{array}$ & Time & $\begin{array}{c}\text { Percentag } \\
\text { e (\%) }\end{array}$ \\
\hline 1 & $\begin{array}{l}\text { Student Activity Is } \\
\text { Actively Moving / } \\
\text { Practicing. }\end{array}$ & 25 & $35 \%$ \\
\hline 2 & $\begin{array}{l}\text { Time Used For } \\
\text { Information From } \\
\text { Lecturers To } \\
\text { Students }\end{array}$ & 10 & $10 \%$ \\
\hline 3 & $\begin{array}{l}\text { Time Used For } \\
\text { Kedeng Smash }\end{array}$ & 30 & $30 \%$ \\
\hline 4 & $\begin{array}{l}\text { Students Waiting } \\
\text { (Not Moving) / } \\
\text { Waiting For Their } \\
\text { Turn }\end{array}$ & 5 & $5 \%$ \\
\hline
\end{tabular}

\begin{tabular}{l|l|c|c}
\hline 5 & $\begin{array}{l}\text { Time Used For } \\
\text { Lecturers To } \\
\text { Manage Classes }\end{array}$ & 10 & $10 \%$ \\
\hline 6 & $\begin{array}{l}\text { Students Free } \\
\text { And Inactive In } \\
\text { Learning }\end{array}$ & 10 & $10 \%$ \\
\hline \multicolumn{2}{c}{ Total } & 90 & 100 \\
\hline
\end{tabular}

Table 2. Assessment Results Aspects observed from students, pre-cycle and Cycle 1

\begin{tabular}{l|c|c|c}
\hline \multirow{2}{*}{ s } & $\begin{array}{c}\text { Cycle to } \\
\text { Cycle }\end{array}$ & Yes & No \\
\cline { 2 - 4 } & Pre-Cycle & 2 & 4 \\
\cline { 2 - 4 } 1. Preliminary & Cycle 1 & 3 & 3 \\
\hline \multirow{2}{*}{$2 . \quad$ Core } & Pre-Cycle & 2 & 4 \\
\cline { 2 - 4 } & Cycle 1 & 4 & 2 \\
\hline \multirow{2}{*}{$3 . \quad$ Closing } & Pre-Cycle & 2 & 4 \\
\cline { 2 - 4 } & Cycle 1 & 4 & 2 \\
\hline
\end{tabular}

Table 3. Assessment Results Observed aspects of the Lecturer, Pre-cycle and Cycle 1

\begin{tabular}{l|c|c|c}
\hline \multirow{2}{*}{ Indicator: } & $\begin{array}{c}\text { Cycle to } \\
\text { Cycle }\end{array}$ & Yes & No \\
\hline \multirow{2}{*}{ 4. Preliminary } & Pre-Cycle & 3 & 3 \\
\cline { 2 - 4 } & Cycle 1 & 5 & 1 \\
\hline \multirow{2}{*}{ 5. Core } & Pre-Cycle & 3 & 3 \\
\hline \multirow{2}{*}{ 6. Closing } & Cycle 1 & 5 & 1 \\
\hline & Pre-Cycle & 2 & 4 \\
\cline { 2 - 4 } & Cycle 1 & 3 & 3 \\
\hline
\end{tabular}

Reflection of the first cycle

Reflection on improvement is an analysis of the results of the research data collected and the learning process involving a colleague of research members and 3 student representatives, the results of the discussion obtained the following findings:

1. Problems that occur in students, among others: only a small proportion of students still show less attitude seriously, students are still not actively practicing, there are still students who are less concerned about learning activities that are presented with a 
hanging ball. According to the table above, the effective time for students to practice is only $35 \%$ of 90 minutes of learning, and students are free outside the learning activities recorded for $10 \%$, and the remaining time is used for class management, time waiting for their turn to move, and information from lecturers to students.

2. Mastery in learning for students and lecturers in the first cycle when compared with pre-cycle data, has not shown a significant improvement. New improvements occurred in the level of success seen from the observation sheet.

3. Although an increase in learning as a whole has not seen a significant improvement but the progress of students. The improvement is shown based on the observation results of students and lecturers in the table above, that:

a) Preliminary aspects observed from students consist of 6 assessments. Follow the learning process Pre cycle Yes (2) and No (4). Whereas the assessment after the first cycle of Yes (3) and No (3) the improvement was not significant enough.

b) The core aspects observed from students consisted of 6 assessments, following the learning process Pre-cycle Yes (2) and No (4). Whereas the assessment after the first cycle of Yes (4) and No (2) the improvement was not significant enough.

c) Concluding aspects were observed from students there were 6 ratings. follow the learning process Pre cycle Yes (2) and No (4). Whereas the assessment after the first cycle of Yes (4) and No (2) the improvement was not significant enough.

d) The preliminary aspects observed from the lecturers consisted of 6 assessments. Following the learning process Pre cycle Yes (3) and No (3). Whereas the assessment after the first cycle of Yes (5) and No (1) the improvement was not significant enough.

e) The core aspects observed from the lecturers consisted of 6 assessments, following the learning process Pre-cycle Yes (3) and No (3). Whereas the assessment after the first cycle of Yes (5) and No (1) the improvement was not significant enough.

f) Concluding aspects were observed from lecturers there were 6 ratings. follow the learning process Pre cycle Yes (2) and No (4). Whereas the assessment after the first cycle of Yes (3) and No (3) the improvement was not significant enough.

4. Findings Problems that arise in the first cycle: Students and lecturers are not good in the learning process so the improvement results have not been significant.

Second cycle

1) Planning of Second Cycle

- The findings in the first cycle are the researchers' reference for planning the next research steps. The first step is to identify data on the results of student skills tests, the results of observations in the first cycle Then the findings of the problems in the second cycle are of particular concern to be solved in the next learning action.

- Research planning in the second cycle, researchers have prepared a Semester Learning Plan by applying instructional audio-visual video media, presented in 2 meetings (sub-actions).

- The number of members in each group is 6 people (the same as learning cycle 1).

- The number of groups in this cycle is 5 groups.

2) Implementation of Actions

In the second cycle of learning, 2 meetings were held, namely 19 and 26 September 2019, this learning action was carried out for 2 lesson hours $(2 \times 50$ minutes). The application of hanging balls is presented in the form of group exercises done with the following learning steps:

3). Results of Observation of Cycle 
a. During the second cycle learning process which was presented in 2 meetings the researchers noted several things, including students very motivated to do the kedeng smash kick exercise with a hanging ball.

b. Observation using the lecturer and student observation sheets during learning taken 6 students randomly. Students who are sampled are a representation of all students who represent and show the conditions of learning in the class. Observation of the activities of students and lecturers recorded for 90 minutes at the first meeting with the data in the following table:

(1) Classically / together students observe the kedeng smash instructional video through the hanging ball media which is aired via Infokus.

(2) Students observe carefully, and note the important things of each movement from the beginning to the end together.

(3) Each group gradually practiced the kick technique through the hanging ball media repeatedly and focused on doing the Smash During the learning.

Table 4. Assessment Results Observed aspects of students, pre-cycle and Cycle 2

\begin{tabular}{l|l|c|c}
\hline \multirow{2}{*}{ Indicators: } & \multicolumn{1}{|c|}{$\begin{array}{c}\text { Cycle to } \\
\text { Cycle }\end{array}$} & YES & NO \\
\hline \multirow{2}{*}{ 7. Preliminary } & Pre-Cycle & 3 & 3 \\
\cline { 2 - 4 } & Cycle 2 & 5 & 1 \\
\hline \multirow{2}{*}{ 8. Core } & Pre-Cycle & 4 & 2 \\
\cline { 2 - 4 } & Cycle 2 & 5 & 1 \\
\hline \multirow{2}{*}{ 9. Closing } & Pre-Cycle & 4 & 2 \\
\cline { 2 - 4 } & Cycle 2 & 6 & 0 \\
\hline
\end{tabular}

Table 5. Evaluation Results of Observed Aspects of Lecturers, Pre Cycle and Cycle 2

\begin{tabular}{l|c|c|c}
\hline \multicolumn{1}{c|}{ Indicators: } & $\begin{array}{c}\text { Cycle to } \\
\text { Cycle }\end{array}$ & Yes & No \\
\hline \multirow{2}{*}{ 10. Introduction } & Pre Cycle & 4 & 2 \\
\cline { 2 - 4 } & Cycle 2 & 5 & 1 \\
\hline \multirow{2}{*}{ 11. Core } & Pre Cycle & 4 & 2 \\
\cline { 2 - 4 } & Cycle 2 & 5 & 1 \\
\hline \multirow{2}{*}{ 12. Closing } & Pre Cycle & 5 & 1 \\
\cline { 2 - 4 } & Cycle 2 & 6 & 0 \\
\hline
\end{tabular}

\section{Second cycle reflection}

Reflection on improvement is an analysis of the results of the research data collected and the learning process involving a colleague of research members and 3 student representatives, the results of the discussion obtained the following findings:

1. Problems that occur in students, among others: only a small proportion of students still show less attitude seriously, students are still not actively practicing, there are still students who are less concerned about learning activities that are presented with hanging ball media. According to the table above, the effective time for students to practice is only $35 \%$ of 90 minutes of learning, and students are free outside the learning activities recorded for $10 \%$, and the remaining time is used for class management, time waiting for their turn to move, and information from lecturers to students.

2. Mastery in learning for students and lecturers in the second cycle when compared with pre-cycle data, has shown a improvement. New improvements occurred in the level of success seen from the observation sheet.

Although an increase in learning as a whole has seen an increase, but the progress of students. The improvement is shown based on the observations of the 
students in the table above, that: Although the learning increase has not seen a significant improvement but the progress of students. The improvement is shown based on the results of observations of students and lecturers in the table above, that:

a. The preliminary aspects observed from students consisted of 6 assessments. Following the learning process Pre cycle Yes (3) and No (3). Whereas the assessment after the first cycle of Yes (5) and No (1) the improvement was quite significant.

b. The core aspects observed from students consisted of 6 assessments, following the learning process Pre-cycle Yes (4) and No (2). Whereas the assessment after the first cycle of Yes (5) and No (1) the improvement was quite significant.

c. Concluding aspects were observed from students there were 6 ratings. follow the learning process Pre cycle Yes (4) and No (2). While the assessment after the first cycle of Yes (6) and No (0) the improvement was quite significant.

d. The preliminary aspects observed from the lecturers consisted of 6 assessments. Following the learning process Pre cycle Yes (4) and No (2). Whereas the assessment after the first cycle of Yes (5) and No (1) the improvement was quite significant.

e. The core aspects observed from the lecturers consisted of 6 assessments, following the learning process Pre-cycle Yes (4) and No (2). Whereas the assessment after the first cycle of Yes (5) and No (1) the improvement was quite significant.

f. Concluding aspects were observed from lecturers there were 6 ratings. follow the learning process Pre cycle Yes (5) and No (1). While the assessment after the first cycle of Yes (6) and No (0) the improvement has been significant.

Findings that appear in the second cycle:

a. Students and lecturers are already good in the learning process so that the result is significantly increased.
The results of students observations in teaching and learning process by kedeng Smash through the media of ball hanging in cycle I amounted to $55 \%$ of all observations of the teaching and learning process. In the second cycle increased to $85 \%$. While the observations of lecturers in the first cycle were $60 \%$ and increased in the second cycle to $85 \%$. So it can be concluded that there is a very significant increase in kedeng Smash learning application through hanging ball media to Physical Education students.

\section{CONCLUSION \\ Conclusions}

Based on the results of research in the chosen subject course of Sepak Takraw, the improvement of the teaching and learning process of Sepak Takraw by kedeng smash through hanging ball media. This research was conducted during Physical Education hours. The research method used was classroom action research (CAR), this research object are physical research subjects about 33 students. This research was conducted in 2 cycles, each cycle consisting of four stages, namely: (1) introduction, (2) main core, (3) closing. The data collected type is qualitative data in the form of observations of lecturer and student activities during the teaching and learning process takes place. Based on teaching observations and learning process on kedeng Smash through a hanging ball on Sepak Takraw. In the pre cycle, cycle I and cycle II, there was an increase in the teaching and learning process in Smash learning for students, in cycle I the observing teaching value and learning process towards students only carried out 10 points or if presented represented $50 \%$ of the overall assessment in the learning process and teaching, then in the second cycle the value of observing the teaching and learning process towards students increased to 15 points or if presented presented increased to $80 \%$. While the 
teaching process of kedeng smash lecturers also increased, in the first cycle the observation value of the teaching and learning process for lecturers only carried out 12 points or $60 \%$ of the overall assessment in the teaching and learning process, then in the second cycle the observation value of the teaching and learning process for lecturers increased to 16 points or when presented to $85 \%$. Thus seen from the pre cycle, cycle I and cycle II above, it can be said that the application of kedeng Smash learning through the hanging ball media can improve the results of the teaching and learning process of students in the chosen course of Sepak Takraw on the UNIB Physical Education campus.

\section{Suggestion}

Based on the research revealed above, the researcher recommends the Physical Education teacher/lecturer practitioners and other researchers the following matters;

1. For Physical Education teachers/ lecturers who have difficulty in teaching students to improve kedeng Smash in Sepak Takraw through hanging ball media and can modify other media to facilitate students in practicing Smash on Sepak Takraw to improve active and innovative learning processes in improve skills.

2. The students should continue to be active in the teaching and learning process, especially in the understanding kedeng Smash in Sepak Takraw.

3. For other researchers mush be able to follow up the research into the application of kedeng smash by hanging ball media in Sepak Takraw so that the implementation is successful and better.

\section{REFERENCES}

Darwis \& Basa. (1992).Olahraga Pilihan Sepaktakraw. Padang : Depatremen Pendidikan dan Kebudayaan
Direktorat Jenderal Pendididkan Tinggi Proyek Pembinaan Tenaga Kependidikan.

Hamidi,Ahmad.(2007).Sepaktakraw(Konse p\&Aplikasi).Bandung:Prodi PJKR UPI.

Muhammad Muhsin. (2008). Skripsi. Tingkat Keterampilan Bermain Sepaktakraw Mahasiswa PJKR Non Reguler Fakulta IImu Keolahragaan Universitas Negeri Yogyakarta. Yogyakarta: FIK UNY.

Nurhasanah, 2008, Penilaian Pembelajaran Penjas, Jakarta: Universitas Terbuka.

Pernandes, A., \& Sutisyana, A. (2018). Pengaruh Latihan Bola Gantung Terhadap Kemampuan Smash Kedeng Dan Smash Gulung Dalam Permainan Sepak Takraw Pada Atlet Psti Kabupaten Lebong. Kinestetik, 2(1), 89-96.

Peter Simson,(2008) Teknik Bermain Pimpong Bandung : CV Pioneer Jaya.

Rusli,Uus. (2009). The world Of Sepak

Takraw. Ciamis : PJKR UNIGAL Ciamis.

Samsudin,(2008) Pemanfaatan Lingkungan dalam Pembelajaran Penjas, Jakarta: Universitas Terbuka.

Sucipto, B., \& Sugiyanto, S. (2017). Upaya Meningkatkan Kemampuan Sepak Sila Melalui Variasi Latihan Berpasangan Pada Permainan Sepak Takraw Siswa Kelas V Sd Negeri 18 Kota Bengkulu. Kinestetik, 1(1).

Sudrajat Prawirasaputra. (2000). Sepak Takraw. Jakarta : Direktorat Jendral Olahraga.

Tim Mengajar Sepak Takraw (2006). SepakTakraw, PSTI Sumbar: Padang.

Toto Subroto, (2008), Strategi Pembelajaran Penjas, Jakarta: Universitas Terbuka.

Winarno M.E (2004). Pengembangan Permainan SepakTakraw, Disertasi Program Pasca Sarjana Universitas Negeri jakarta: Jakarta. 
Yusuf Ucup, dkk (2001). Pembelajaran Permainan SepakTakraw, Direktorat Jenderal Pendidikan Dasar dan Menengah: Jakarta.

Zalfendi, dkk (2009). Permainan

SepakTakraw, Sukabina Press:

Padang. 